\title{
Ideality Versus Reality of Minimum Wage in Indonesia's Labor Law Regulation
}

\author{
Andreas Andrie Djatmiko ${ }^{1}$, Ahmad Izzul Ito $^{2}$ \\ \{andreas.djatmiko@stkippgritulungagung.ac.id ${ }^{1}$ \}
}

STKIP PGRI Tulungagung ${ }^{12}$

\begin{abstract}
The minimum wage is set once a year after preceded by a survey on figures obtained Living Needs (KHL). The Manpower Office together with the Wage Council calculates the KHL value according to the survey results. With the ideality of the components surveyed, it can classify into five groups: food and beverage groups; fuel and lighting group; housing and equipment groups, clothing groups and other groups. In calculating, the final value of KHL has also considered other factors that influence it such as inflation rates, economic growth, minimum physical needs, company ability and comparison of wage rates in other regions.

However, the reality of the facts, especially in the area of Tulungagung Regency, East Java Province, on average the UMK (Regency / City Minimum Wages) as the recent policy of the government only meet around $90 \%$ or even less, precisely to fulfill the existing Minimum Living Needs (KHM). So, this raises a fundamental problem, which focuses on the issue of ideality and reality of UMK (Regency / City Minimum Wages) as the recent policy of the government. In order to establish the Regional Minimum Wage Regulation (UMR), which is carried out by the Provincial Government, especially in East Java Province, the basis for consideration is the establishment of Regional Minimum Wages, they are: Minimum Living Needs (KHM), Consumer Price Index (IHK), expansion of employment opportunities, wages in general that apply regionally, the ability, development, and continuity of the company, and the level of economic development.
\end{abstract}

Keywords: Regency / City Minimum Wage (UMK), Ideality, Reality, and Regulation.

\section{Introduction}

The Determination of salaries and wages of employees does look unimportant, but in the implementation, it is very complex especially for the companies that do not have an objective of salary payment system for their employees. A good and correct salary-giving system is one of the most important factors in the company because it also determines the productivity of a company. In the determination of employee salary, have to appropriate indicator.

The minimum wages set once a year after preceded by a survey on figures obtained Living Needs (KHL). The Manpower Office together with the Wage Council calculates the KHL value according to the results of survey. The ideal of the components surveyed can be classified into five groups; there are food and beverage groups; fuel and lighting group; housing and equipment groups, clothing groups and other groups. In calculating, the final value of KHL has also considered other factors that influence it such as inflation rates, economic 
growth, minimum physical needs, company ability and comparison of wage rates in other regions.

However, the reality of the facts, especially in the area of Tulungagung Regency, East Java Province, on average the UMK (District / City Minimum Wages) only meet around 90\% or even less, precisely to fulfill the existing Minimum Living Needs (KHM). Therefore, it can make a fundamental problem, which focuses on the issue of ideality and reality of "UMK" (Regency / City Minimum Wages). In determining the Regional Minimum Wages (UMR) Regulations by the Provincial Government, especially East Java Province, the basis for consideration is the determination of Regional Minimum Salaries, there are: Minimum Living Needs (KHM), Consumer Price Index (IHK), expansion of employment opportunities, salaries in general that apply regionally, Capability, development, and continuity of companies, and Level of economic development. The objectives of this UMP arrangement are : (1) to keep the wage level from falling down (functioning as a safety net), (2) to improve the lowest buying power of workers, and (3) to reduce the gap between the highest and Lowest income.

\section{Research Problems}

From the kinds of problems, the focus of the problem is: How the ideality and reality of UMK (Regency / City Minimum Wages) as the recent policy of the government in reviewed from Regulations of Labor Law in Indonesia?

\section{Objective Of The Research}

To socialize and give education to the general public about the Applicable Labor Law Regulations to determine the Regency / City Minimum Wage, and the components used in establishing these regulations so as to create synchronization of ideality and reality of UMK (Regency / City Minimum Wages) as the recent policy of the government especially in Tulungagung Regency, East Java Province

\section{Method}

The method in this research is an empirical or non-doctrinal juridical method which is intended as an effort to approach the problem of the research with the nature of the law in accordance with the reality that lives in society. The approach used sociological/empirical using a non-positivistic approach and qualitative research. With qualitative research, there are using a natural background, to interpret the phenomena of using kinds of method. 


\section{Review Of Related Literature}

\section{Minimum Wage Theoretical and its Supporting Components}

\subsection{Definition of Minimum Wages}

The minimum wage is a minimum standard used by entrepreneurs or industry players to provide wages to workers in their business or work environment. Because the fulfillment of adequate needs in each province is different, so is the fulfillment of needs in each district and city (district/city), which is often known as the Regency / City Minimum Wage (UMK) as the recent policy of the government.

In the Manpower Act Number 13 of 2003 Article 88 section 4 says[1]:

"The government sets the minimum wage as referred to in section (3) letter a based on the need for decent living and by paying attention to productivity and economic growth."

An explanation of minimum wages is also contained in the Manpower Act Article 89 explaining[1]:

1) The minimum wage as referred to in Article 88 section (3) letter a can consist of:

a. Minimum wage based on province or regency / city area;

b. Minimum wages based on sectors in the province or regency / city

2) The minimum wage as referred to in Article 88 section 3 (1) is directed at achieving decent living needs.

3) The minimum wage as referred to in section (1) is stipulated by the Governor by taking into account the recommendations of the Provincial and / or Regents / Mayors Wages Council.

4) Components and the implementation of the stages of achieving figures obtained Living Needs as referred to in section (2) shall be regulated by a Ministerial Decree.

Meanwhile, if referring to Labor Law number 13 of 2003, article 94[1], it is stated that; "The wage component consists of basic wages and fixed allowances, so the amount of basic wages is at least $75 \%$ of the total basic wages and fixed allowances".

Minimum wage policy in Indonesia is an important foundation for the government in its efforts to improve the living standards of workers. Ministerial Regulation No.7 of 2013 Article 1 number 1 defines the minimum wage as follows[2]:

"Minimum Wage is the lowest monthly wage consisting of basic wages including fixed allowances set by the Governor as a safety."

\subsection{Objective of Determination Minimum Wage}

According to with Minister of Manpower Regulation Number 7 of 2013[2], the considerations of minimum wage setting in Indonesia are as follows:

1) To protect the wages of workers/laborers so as not to decline at the lowest level due to labor market imbalances, it is necessary to harmonize minimum wage policies by paying attention to productivity and economic growth in order to realize business continuity and improve worker/laborer welfare;

2) Based on these considerations it is necessary to regulate provincial or district / city minimum wages, provincial or district / city sectoral minimum wages, and minimum wages for certain labor-intensive industrial companies. 


\subsection{Basic and Minimum Wage Determination Authority}

According to to article 3 number (1) Ministerial Regulation No.7 of 2013 [2], the stipulation of minimum wages based on figures obtained Living Needs (KHL) with regard to productivity and economic growth.

At this moment, the feasibility of a minimum wage standard is based on the needs of workers in accordance with the Minister of Manpower and Transmigration Regulation of the Republic of Indonesia Number 13 of 2012 concerning Components and Implementation of Stages of Achieving figures obtained Living Needs. In article 2 of the Regulation of the Minister of Manpower and Transmigration of the Republic of Indonesia Number 13 of 2012, it is stated that KHL consists of components and types of needs as seen in Appendix I of this Ministerial Regulation[3].

Using price survey guidelines the value of figures obtained Living Needs (KHL) is as follows;

1) Establishment of the KHL Survey Team by the Head of the Council or Regents / Mayors

2) Survey Implementation included a. The questionnaire, b. The setting, c. Survey Time, d. Respondents, e. Price Survey Method, f. Determination of Specifications for Needs (Price Parameters)

Unfortunately, there is no clear direction on how other information besides KHL be collected and used to set standards of the minimum wage, both at the local and national level. Wage councils at the provincial and Regency / city levels are required to play a key role in conducting research and making recommendations to local governments in revising standards of the minimum wage, which based on estimates of changes in the determination of the KHL standard.

\subsection{Kinds of Minimum Wage}

According to Minister of Manpower and Transmigration Regulation Number 7 of 2013 concerning Minimum Wages, various types of minimum wages mentioned, namely as follows[2];

1) Provincial Minimum Wage (UMP) is the Minimum Wage that applies to all districts / cities in one province.

2) Regency / City Minimum Wage (UMK) is the Minimum Wage applicable in the regency / city area.

3) Provincial Sectoral Minimum Wage (UMSP) is a Minimum Wage that applies sectorally in one province.

4) Regency / City Sectoral Minimum Wages (UMSK) are Minimum Wages that apply sectorally in the district / city area. 


\section{Discussion}

\subsection{Ideality Versus Reality Of Minimum Wage In Indonesia's Labor Law Regulation. The Ideal Payroll And Wages System For Workforce In Accordance With Reality}

Companies that have implemented a payroll and wage system well, can be seen from the procedures that make up the payroll and wage systems that have been implemented by the company concerned. The procedures that make up the payroll and wage system consist of a. The procedure for recording the time of attendance of labor; $b$. Procedure for recording the work time of labor; c. Procedures for making salary and labor wages; d. Procedure for distribution of salary and wage costs; e. Procedure for paying salaries and wages.

Salaries and wages are something that is very sensitive between the company and the workforce. Workers must work hard to get their rights with a salary or wage from the company. The company must be able to carry out its obligations to fulfill its employees' rights objectively. If one party does not carry out its obligations or does not get its rights, it is certain that the balance between the company and the workforce will not occur. The production process will not run well, the welfare of the workforce not fulfilled. The indicators used in determining salaries and wages are:

1) Labor Hours

Determination of salaries and wages for workers can be based on labor hours guided by attendance card hours and working hours cards. If the working hours of labor are getting longer, the salary or wages given to the workforce are getting bigger, because the employee gets additional income.

2) Labor Achievement

Labor Achievement can measure through labor productivity in producing a product. Labor Achievement can also be achievements of the company that have been achieved by the workforce, for example, the company gets an award in the sale of products, so that it can increase the salary and wages of labor. The history of labor education is also a consideration in determining the salary size and position of the workforce in a company. In addition, work experience in the company or other companies also has a stake, because it will affect the skills and productivity of the workforce so that it can improve the work performance of the workforce compared to workers who do not have work experience at all.

3) Regency / City Minimum Wages

Salaries and labor wages will be high if the (UMK) in the workplace area are also high. The Regency / City Minimum Wage also influence the determination of the salary and wages by a company other than the two indicators above. The Regency / city minimum wage prepared by the district / city government to determine the minimum salary or wage received by workers in the area. This by the regional government to protect the workforce in their respective regions. The amount of UMK (Regency / City Minimum Wages) as the recent policy of the government is an agreement between employers and workers brokered by the government. In addition, analysis from experts by considering KHL (figures obtained living Needs), economic growth, inflation rates, and unemployment rates were also considered in determining UMK.

In its reality, especially in the area of Tulungagung Regency as is known in the Governor Regulation (Pergub) of East Java (East Java) number 75 in 2017 concerning the Regency / 
City Minimum Wage in 2018 the amount of UMK is stated to be 1,671,035.77 rupiahs. Even though there is an increase of $8 \%$ from UMK in 2017, this UMK amount if it is adjusted to the definitive KHL contained in Presidential Regulation number 78 of 2015[4] is considered very far from the standard of decent living needs in which the KHL has several components consisting of: a. Food and Beverages (11 components); b. Clothing (13 components); c. Housing (26 components); d. Education (2 components); e. Health (5 components); f. Transportation (component); g. Recreation and Saving money (2 components).

\subsection{Regency / City Minimum Wage (UMK) Policy Viewed From Applicable Labor Law Regulations}

\section{Minimum Wages Viewed From Applicable Regulations}

According to Minister of Manpower and Transmigration Regulation Number 7 of 2013 Article 1 number 1 [2], Minimum Wage is the lowest monthly wage consisting of basic wages including fixed allowances set by the governor as a safety net.

If we refer to Article 94 of Act No. 13 of 2003 concerning Manpower[1], the wage component consists of basic wages and fixed allowances, the amount of basic wages is at least $75 \%$ of the total basic wage and fixed allowance[1]. The definition of a fixed allowance here is a benefit for which payments made regularly and are not associated with attendance or work achievement, for example position allowance, communication allowance, family allowance, professional / professional allowance. Unlike the case with food and transportation allowances, the allowances are non-fixed because the calculation is based on attendance or work performance.

For this reason, besides being regulated in Act No. 13 of 2003 concerning Manpower, regulations related to wage setting mechanisms are also described in the latest Government Regulation, namely Government Regulation number 78 of 2015 concerning wages, so employers should provide minimum wages and basic wages. In accordance with existing regulations, considering the wages stipulated in law number 13 of 2003 and Government Regulation number 78 of 2015 concerning wages can be interpreted differently. This can be seen in article 5 section (1), (2) and (3) and article 41 section (2) Government Regulation number 78 of 2015.

\section{Minimum Wages and Problems}

In Tulungagung Regency, now the minimum wage policy is still a reference for wages for workers. The rationale for setting minimum wages is that minimum wages are a step towards achieving decent income to achieve workers' welfare to pay attention to the productivity and progress of the company.

Law number 13 of 2003 concerning Manpower mandates that the minimum wage received by workers should be able to meet figures obtained Living Needs (KHL). This law then translated into Minister of Manpower Regulation No. 13 of 2012 [5] concerning Components and Implementation of Stages of Achieving figures obtained Living Needs, which stipulates that the value of each component and type of KHL obtained through periodic price surveys. This is the quality, and technical specifications of each component and type of KHL agreed before the survey carried out, and determined by the head of the Provincial or the Regency / City Wage Council.

From the Entrepreneur's side the Employers 'objection to the annual increase in minimum wages considered a burden while on the Workers' side the problem that arises includes not 
complying with the provisions of the minimum wage power to pay the minimum wage, which on average can only fulfill $80 \% \mathrm{KHL}$ as the basis for determining minimum wages.

Another problem is that the minimum wage policy only intended for single workers with a work period of less than one year, then also applies to workers with a work period of more than one year and maximum wages because employers generally do not want to pay more than the minimum wage. Because it is also applied to workers with a work period of more than one year and most of them are already married, the minimum wage whose calculation based on the KHL of single workers is unable to meet the living needs of families of married workers.

The minimum wage, which is set by the government is uncertain because it is possible to deviate from the provisions. It makes the wages received by workers or laborers are under the standard of figures obtained Living Needs requirements, as stated in the provisions of Article 90 section (1) of the Manpower Act which regulates the prohibition of paying more wages the low of the minimum wage is not mandatory in the presence of Article 90 section (2) and its explanation. The regulation has opened opportunities for entrepreneurs who are unable to pay the minimum wage to suspend payments.

\section{Alternative of Salary Adjustment According to Minimum Wages}

According to Law No. Article 13 of In according to Law No. Article 13 of 2003 stipulates that employers prohibited from paying wages lower than the minimum wage. The UMK magnitude of 2018 in the area of Tulungagung Regency is determined based on the Decree of the Governor of East Java No. 75 of 2017 dated November 17, 2017[6]. Submission of suspension for companies that object to the amount of UMK that have been decided has passed.

Thus, company managers must commit to paying their employees according to the provisions. If the employer pays wages lower than the stipulated UMK, he will be liable to imprisonment sanctions of at least 1 (one) year and no later than 4 (four) years and / or a fine of at least 100,000,000.00 rupiahs (one hundred million rupiahs) and a maximum of 400,000,000.00 Rupiahs (four hundred million Rupiahs). The sanctions as mentioned in article 185 of Law No. 13 of 2003 concerning Manpower.

There are several types of compensation paid to employees with a fixed amount each month, including:

1) Basic pay, given to employees according to their level of education and working period

2) Functional allowances, given to employees in accordance with the functions of the field of work, expertise, and skills

3) Expense allowances, given to employees as an additional salary for overpriced assistance, which is usually due to an increase in the price of daily necessities or adjusting the cost of living in a certain place

4) Position allowances, given to structural officials in recognition of their responsibilities.

To facilitate adjustments in payroll, payroll methods should be applied using system points. This system is more flexible and easy to understand by employees. In order for the increase in UMK not to 'burden' too high on the company's total expenditure for a given period, it is necessary to increase points alternately for each of the fixed compensation. For example, the basic salary of employees will increase by several points each year automatically, and a review of rupiahs rates per point is made in no more than 2 (two) years.

For office benefits, it is not a problem, because employees who receive office benefits usually have an income far above the minimum wage provisions. However, it be evaluated so that the amount of this allowance is always in accordance with the responsibilities carried out 
by the employees who occupy the position. The principle of internal and external Consistency in remuneration always be fulfilled.

\section{The Component of Salary}

Included in East Java Governor Regulation No. 75 of 2017 dated 17 November 2017[6], MSEs only apply to workers who have a work period of less than 1 (one) year. This means that this UMK is only a component of a fixed salary minimum wage. Minimum wages not related to variable salaries.

However, variable salaries given with several objectives, including motivating employees is more diligent in coming to the office, if the calculation based on attendance. Variable payroll intended to improve employee discipline, if the calculation based on order of coming/leaving work. Another goal is to increase work productivity if the calculation based on the number of jobs that be completed in a given period. By judging a number of these objectives, it is clear that variable payroll also plays an important role in increasing company productivity.

Because in reality, it is often that the amount of the allowance becomes greater than the basic salary received by a worker. Because the allowance is large, the take-home pay felt to have exceeded the minimum wage, even though the minimum wage only consists of basic salary and fixed allowance where the non-fixed allowance is not a variable included in the overall salary calculation process.

List of 2018 Regency / City Minimum Wages by East Java Governor Regulation No. 75 of 2017 dated November 17, 2017

In East Java Province has issued a 2018 UMK list. Looking at the existing MSE Amount, the Regency / City Minimum Wage in 2018 sufficient to increase compared to yesterday's Minimum wage.

For East Java itself, the value of the salary amount for the city of Surabaya also balanced by the industrial ring road area in the surrounding cities, which also exceeded 3.5 million, only 5 to 10 thousand rupiahs like East Java in 2017. This value shows the spread of industry and economy, which quite evenly distributed in the industrial area of Surabaya and its supporting cities look stable and tend to be dynamic.

Whereas specifically in the Tulungagung Regency area itself the increase in UMK ranges from $8 \%$ compared to 2017, which is from the amount of 1,537,150.00 Rupiahs (UMK 2017) to $1,671,035.77$ Rupiahs.

By the data from East Java Governor Regulation No. 75 of 2017 dated November 17, 2017, there are Regency/City Minimum Wages in 2018, then the Regional Government, especially the Regency/City of Tulungagung, should be able to calculate effectively and efficiently what the Regional Minimum Wage (UMR) is about without sacrificing one of the parties is between workers and entrepreneurs. Incorrect calculations will have a negative impact on the economy of the Region, and it can even disrupt the stability of the central economy, and it is feared to disrupt the Indonesian economy. Therefore, in determining the Regional Minimum Wage, it must be based on the results of the KHL (figures obtained Living Needs) survey conducted by the Wage Council which consists of representatives of trade unions, employers, governments, and neutral parties from academics. The number of UMK should be greater than the UMP, and each City / Regency has a different value than other cities/districts even in one province. Example: UMP JATIM 3,500,000 Rupiahs; Surabaya City UMK 3,583,312.61 Rupiahs; UMK Malang City 2,470,073.29 Rupiahs; UMK Tulungagung Regency 1,671,035.77 Rupiahs, of course the difference is based on a number of indicators, namely economic 
growth; living needs of workers; purchasing power; inflation rate; and also the ability of companies in their respective regions.

\section{Implementation of Regional Minimum Wages (UMP \& UMK)}

If a company or personal business cannot provide a wage in this amount, the leader must agree with the worker or union at the place of business, and then submit the agreement to the governor for approval. If it not approved then, the place of business must comply with UMK. If approved, it must remember the period of suspension of the number of wages set by the governor. If it has passed the deadline, then it must again comply with the UMK. If there are naughty entrepreneurs, it can report to the DPRD because this is the task of the DPRD to supervise the implementation of government policies.

\section{Regulations in Regional Minimum Wages (UMP \& UMK)}

To ensure adequate wages for workers and guarantee the continuity of business activities in Indonesia, the government made a series of regulations governing wage systems and mechanisms in Indonesia. The regulation of wages consists of 2 (two) main parts, namely:

1) Regulation related to wage setting mechanism

2) Regulation regarding wage protection

Regulations related to the wage setting mechanism regulated in Law No. 13 of 2003 concerning Labor with the following system: a. Determination of minimum wages at the provincial and district/city/ municipal level; b. Determination of wages through collective agreements/negotiations; c. Determination of structure \& wage scale; d. Periodic review of wages

Regulations related to wage protection are regulated in Law No. 13 of 2003 article $88 \mathrm{sec}$ tion 2 concerning Manpower which reads: To realize income that fulfills a decent livelihood for humanity, the government establishes wage policies that protect workers/laborers.

\section{Sanctions For Companies That Violate The Provisions On The Determination Of UMR Policies (UMP \& UMK)}

In accordance with Law No. 13 of 2003 concerning Manpower, entrepreneurs who do not pay wages in accordance with UMP provisions considered as perpetrators of crimes with the threat of prison sanctions from one to four years and a minimum fine of 100 million Rupiahs and a maximum of 400 million Rupiahs. The stipulated UMP is a basic salary for workers who are still unmarried and have a tenure of 0-12 months. In the event that the wage component consists of basic wages and fixed allowances, the amount of the basic wage is at least $75 \%$ (seventy-five percent) of the total basic wages and fixed benefits. Various types of companies in this province have different development. Some have been able to pay far above the minimum, but on the contrary, not a few have not able to implement it.

\section{Conclusion}

The problem of ideality and reality of UMK (District / City Minimum Wages) in terms of Applicable Labor Law Regulations is complex and complicated, especially after knowing the system, substance \& mechanism of labor remuneration and the issue of employer wages and a myriad of problems. The meaning is the Government as a regulator seeks to be fair to try to 
please both parties between workers and employers because workers and entrepreneurs are a couple who need each other. Entrepreneurs are not able to operate smoothly without being supported by labor; on the contrary, labor needs jobs to get wages to meet their daily needs. So from that the role of the government in this case specifically the regional government to be able to be wisely effective and efficient in deciding the amount that is felt right for both parties so as not to feel biased.

It can be concluded that a number of things arise in the perspective of the issue of ideality and reality of UMK (Regency / City Minimum Wages) as the recent policy of the government in terms of the Labor Law Regulations Applicable in the application of Minimum Wages, as well as the implications for policies that must be taken by the government:

1) Ideally, the stipulation of wages set by the Government is the applicable minimum wage regional, sectoral regional or subsectoral regional must be carried out by each company with the understanding that the company may not pay workers' wages under the Minimum Wage Conditions. With the increase in wages, the lowest workers can approach or equal the wage level of the workers above it. Workers who above the Government's Minimum Wage Conditions.

2) The reality of the condition of the company is indeed not possible. This condition is related to a declining business situation, or it can also be caused by large production costs, mainly due to the existence of levies, both official and illegal. Therefore, the government should be obliged to regulate sectoral and subsector-based wage systems with audited indicators of the company's net income as wage scale parameters.

\section{References}

[1] P. R. Indonesia, "UU No 13 Tahun 2003 Tentang Ketenagakerjaan.” Pemerintah Republik Indonesia, Jakarta, pp. 1-30, 2003.

[2] Menteri Tenaga Kerja dan Transmigrasi, "Peraturan Menteri Tenaga Kerja dan Transmigrasi Nomor 7 Tahun 2013 tentang Upah Minimum.” Berita Negara Republik Indonesia Tahun 2013 Nomor 1239, Jakarta, 2013.

[3] Menteri Tenaga Kerja dan Transmigrasi, "Peraturan Menteri Tenaga Kerja dan Transmigrasi Republik Indonesia Nomor 13 Tahun 2012 tentang Komponen dan Pelaksanaan Tahapan Pencapaian Kebutuhan Hidup Layak.” Jakarta, 2012.

[4] Pemerintah Republik Indonesia, "Peraturan Pemerintah Republik Indonesia Nomor 78 Tahun 2015 tentang Pengupahan.” Lembaran Negara Republik Indonesia Tahun 2015 Nomor273, Jakarta, 2015.

[5] Menteri Tenaga Kerja dan Transmigrasi, "Peraturan Menteri Tenaga Kerja dan Transmigrasi Republik Indonesia Nomor 13 Tahun 2012 tentang Komponen Pelaksanaan Tahapan Pencapaian Kebutuhan Hidup Layak.” Pemerintah Republik Indonesia, Jakarta, 2012.

[6] Gubernur Jawa Timur, "Peraturan Gubernur Jawa Timur Nomor 72 Tahun 2014 tentang Upah Minimun Kabupaten/Kota di Jawa Timur Tahun 2015.” Berita Daerah Provinsi Jawa Timur Tahun 2017 NOMOR 75 , SERI E, Jawa Timur, 2014. 